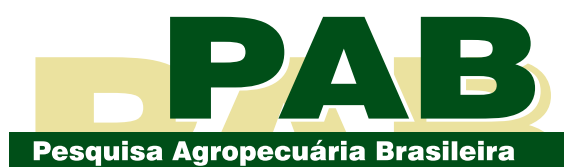

ISSN 1678-3921

Journal homepage: www.embrapa.br/pab

For manuscript submission and journal contents, access: www.scielo.br/pab

\section{Assessment of somaclonal variation in indirect morphogenesis-derived plants of Arracacia xanthorrhiza}

\begin{abstract}
The objective of this work was to induce and detect somaclonal variation in arracacha (Arracacia xanthorrhiza) plants regenerated via indirect morphogenesis, in order to evaluate the potential of this technique to produce new genotypes for breeding purposes of this crop. Calli were induced from petiole segments on Murashige \& Skoog (MS) medium supplied with $0.1 \mathrm{mg} \mathrm{L}^{-1} 2,4$-dichlorophenoxyacetic acid. The regeneration of plants via indirect morphogenesis was carried out on half-strength MS medium without plant growth regulators. Fifteen randomly chosen plants were subjected to flow cytometry and "inter-simple sequence repeat" (ISSR) analysis. Ploidy level remained stable in all tested regenerants $(2 n=4 x=44)$, with no changes in the genome. Eighteen ISSR primers produced a total of 1,584 fragments in all samples. Two ISSR primers produced four polymorphic fragments in $26.7 \%$ of the tested samples. Somaclonal variation in arracacha is a result of plant regeneration via indirect morphogenesis and can be detected by ISSR markers.
\end{abstract}

Index terms: arracacha, ISSR, plant breeding, ploidy level, somatic embryogenesis.

\section{Avaliação de variação somaclonal em plantas derivadas de Arracacia xanthorrhiza por morfogênese indireta}

Resumo - O objetivo deste trabalho foi induzir e detectar a variação somaclonal em plantas de batata-baroa (Arracacia xanthorrhiza) regeneradas por morfogênese indireta, para avaliar o potencial dessa técnica em produzir novos genótipos para o melhoramento dessa cultura. Calos foram induzidos em segmentos de pecíolos no meio de Murashige \& Skoog (MS) suplementado com $0,1 \mathrm{mg} \mathrm{L}^{-1}$ de ácido 2,4-diclorofenoxiacético. A regeneração de plantas pela morfogênese indireta foi realizada em meio de cultura MS meia-força, sem reguladores de crescimento de plantas. Quinze plantas escolhidas aleatoriamente foram submetidas à citometria de fluxo e à análise entre sequências simples repetidas (ISSR). O nível de ploidia manteve-se estável em todas as plantas regeneradas $(2 n=4 x=44)$, sem mudanças no genoma. Dezoito iniciadores ISSR produziram um total de 1.584 fragmentos em todas as amostras. Dois iniciadores ISSR produziram quatro fragmentos polimórficos em $26,7 \%$ das amostras testadas. A variação somaclonal entre plantas de batata-baroa é resultante da regeneração de plantas pela morfogênese indireta e pode ser detectada por meio de marcadores ISSR.

Termos para indexação: batata-baroa, ISSR, melhoramento de plantas, nível de ploidia, embriogênese somática. 


\section{Introduction}

Arracacha (Arracacia xanthorrhiza Bancroft) is a perennial root crop from the Apiaceae family, native to the Andean highlands from Venezuela to Bolivia (Orílio et al., 2013). Currently, it is cultivated in Brazil (Carvalho et al., 2018), a few parts of Central America, and in the Caribbean, also showing potential to be distributed as a root crop in the highlands of tropical areas in Asia and Africa (National Research Council, 1989). The edible portion of the plant consists of tuberous roots containing from 10 to $25 \%$ (fresh weight; FW) starch, which is easily digestible and, therefore, suitable for infants and patients.

Recently, much attention has been paid to disease problems of arracacha because they significantly reduce root production. The bacteria Erwinia spp. is considered to be the most harmful to storage roots, whereas a number of fungi attack different plant organs: Slerotinia sclerotiorum causes the plant and root to rot, and Sclerotium rolfsii, Fusarium sp., Phoma sp. and Rhizopus sp. further damage the roots both in the field and during storage (Hermann, 1997). The vegetative propagation of arracacha also leads to the accumulation of pathogens (Orílio et al., 2013).

Due to the narrow variation found in the arracacha genepool, rare flowering, and the low germination of achenes of up to $30 \%$ (Hermann, 1997), breeding efforts using hybridization are limited in this species. Somaclonal variation represents an alternative tool for obtaining new genetic variability (Krishna et al., 2016), with numerous applications in plant breeding and genetic improvement, which enables breeders to obtain plants tolerant to biotic or abiotic stress, among others (Krishna et al., 2016). This type of variation is characterized by newly generated mutations arising from the tissue culture process (Sato et al., 2011) and has been associated to several factors, such as exposure of unprotected genetic material to chemicals in the medium and non-selective environment, high number of subcultures, length of in vitro cultivation, and type and concentration of the applied plant growth regulators (Bairu et al., 2011). The presence of a disorganized growth phase in the tissue culture is another factor contributing to its occurrence, indicating that significant variation can be detected among plants regenerated from the callus (Bairu et al., 2011).

An efficient and early detection of somaclonal variation is needed to spot variants with useful agronomic traits. Overall, somaclonal variants can be detected using several techniques, which are broadly categorized as morphological, physiological/ biochemical, and molecular (Bairu et al., 2011). Molecular techniques in particular are a valuable, recent tool to detect somaclonal variation. Among the molecular markers, inter-simple sequence repeat (ISSR) ones have been considered appropriate for routine genetic evaluation of in vitro regenerants (Soares et al., 2016) because this method is very simple, fast, cost-effective, highly polymorphic, and does not need any prior sequence information to design the primer (Reddy et al., 2002; Lakshmanan et al., 2007). Chromosomal counts, as well as the detection of DNA content variation using flow cytometry, can provide complementary information about somaclonal variation (Bairu et al., 2011).

The objective of this work was to induce and detect somaclonal variation in arracacha plants regenerated via indirect morphogenesis, in order to evaluate the potential of this technique to produce new genotypes for breeding purposes of this crop.

\section{Materials and Methods}

The used arracacha clone $(2 n=4 x=44)$ was provided by the Botanic Garden of Faculty of Tropical AgriSciences of Czech University of Life Sciences Prague, located in the Czech Republic. Leaves and roots were removed from the leaf rosette, and the basal part (about $2.0 \mathrm{~cm}$ in length) bearing the meristem was sterilized using $96 \%(\mathrm{v} / \mathrm{v})$ ethanol for $15 \mathrm{~s}$ and $1.0 \%(\mathrm{v} / \mathrm{v})$ $\mathrm{NaClO}$ with $0.1 \%(\mathrm{v} / \mathrm{v})$ Tween 20 for $20 \mathrm{~min}$, and then rinsed three times with sterile distilled water. After sterilization, the explant was placed on Murashige \& Skoog (MS) medium (Murashige \& Skoog, 1962), supplemented with $1.0 \mathrm{mg} \mathrm{L}^{-1}$ thiamine, $100 \mathrm{mg} \mathrm{L}^{-1}$ myo-inositol, $30 \mathrm{~g} \mathrm{~L}^{-1}$ sucrose, and $8.0 \mathrm{~g} \mathrm{~L}^{-1}$ agar at $\mathrm{pH}$ 5.7. The culture was incubated at $25 / 23^{\circ} \mathrm{C}$ under a 16/8-hour light/dark regime and at a photosynthetic photon flux density of $35 \mu \mathrm{mol} \mathrm{m} \mathrm{m}^{-2} \mathrm{~s}^{-1}$, provided by cool-white fluorescent tubes. To multiply sufficient plant material for the experiment, regenerated shoots were regularly transplanted to fresh MS medium supplemented with $1.0 \mathrm{mg} \mathrm{L}^{-1}$ 6-benzyladenine (BA) and $0.1 \mathrm{mg} \mathrm{L}^{-1}$ naphthalene acetic acid (NAA) every four weeks, where they were cultivated under the previously described conditions. 
To induce callogenesis, petiole segments of 8-10 $\mathrm{mm}$ in length were placed abaxial surface down on MS medium at $\mathrm{pH} \mathrm{5.7,} \mathrm{containing} 100 \mathrm{mg} \mathrm{L}^{-1}$ myoinositol, $30 \mathrm{~g} \mathrm{~L}^{-1}$ sucrose, $8.0 \mathrm{~g} \mathrm{~L}^{-1}$ agar, and $0.1 \mathrm{mg} \mathrm{L}^{-1}$ 2,4-dichlorophenoxyacetic acid (2,4-D) (Slíva et al., 2010). Four petiole segments were placed in $100-\mathrm{mL}$ Erlenmeyer flasks. A total of 80 explants were used in two replicates. The cultures were maintained under the conditions described before.

After eight weeks of its initial development, the callus was divided into about $1.0-\mathrm{cm}$ parts and transferred to the same type of culture medium. Thereafter, every three to four weeks, the calli were multiplied. The morphogenic calli produced on this medium were then transferred to half-strength MS medium, containing $100 \mathrm{mg} \mathrm{L}^{-1}$ myo-inositol, $30 \mathrm{~g} \mathrm{~L}^{-1}$ sucrose, and $8.0 \mathrm{~g}$ $\mathrm{L}^{-1}$ agar to regenerate the plants. Regenerating plants about $5.0 \mathrm{~cm}$ in height were isolated from each callus and further cultivated on half-strength MS medium.

The percentage of explants producing calli was recorded four weeks after the establishment of the experiment. Calli characteristics, such as color, friability and occurrence of meristematic centers, were observed.

The morphogenic callus, regenerating shoots from the callus, and somatic embryos at the cotyledonary stage obtained during the regeneration process were subjected to the histological analysis. Paraffin sections of explants were prepared for histological observation according to Vondráková et al. (2015). Briefly, samples were fixed in 50\% FAA (formaldehyde, acetic acid, ethanol, and water in proportion 1:1:9:9, respectively) for up to 100 hours. After fixation, the tissues were dehydrated using a standard ethanolbutanol dehydration series and then were embedded in paraffin wax at $58-60^{\circ} \mathrm{C}$. The paraffin blocks were cut into thin-section ribbons of $13 \mu \mathrm{m}$ using the Thermo Scientific Shandon Finesse rotary microtome (Fisher Scientific UK Ltd, Loughborough, UK). The sections were stained with $0.1 \%$ Alcian blue in $3.0 \%$ acetic acid and with $0.1 \%$ nuclear fast red in $5 \% \mathrm{Al}_{2}\left(\mathrm{SO}_{4}\right)_{3}$, being photographed afterwards using the Eclipse $80 \mathrm{i}$ microscope equipped with the Digital Sight DS-5Mc camera (Nikon, Tokyo, Japan). All chemicals for the in vitro cultures and histological analysis were purchased from Sigma Aldrich, now Merck (Merck KgaA, Darmstadt, Germany).
Fifteen randomly chosen in vitro regenerants of arracacha were subjected to the ISSR analysis (Zietkiewicz et al., 1994). Genomic DNA was extracted from $100 \mathrm{mg}$ fresh leaf samples with the Invisorb Spin Plant Mini Kit (Invitek Molecular, Berlin, Germany). DNA quality was determined by $1.0 \%$ agarose gel electrophoresis in $1 \times \mathrm{TBE}$ buffer, and DNA concentration was measured on the NanoDrop spectrophotometer (Thermo Fisher Scientific, Waltham, MA, USA). The isolated DNA samples of arracacha were prepared in aliquots of the individual samples at a concentration of $50 \eta \mathrm{g} \mu \mathrm{L}^{-1}$ for polymerase chain reaction (PCR) and then stored at $-20^{\circ} \mathrm{C}$.

A set of 20 ISSR primers obtained from University of British Columbia, located in Canada, was used for screening. DNA amplifications using PCR were carried out in a reaction volume of $20 \mu \mathrm{L}$, with the following composition: $10 \mu \mathrm{L} \times \mathrm{PPP}$ Master Mix [150 mmol L-1 Tris- $\mathrm{HCl}, \mathrm{pH} 8.8$ at $25^{\circ} \mathrm{C}, 40 \mathrm{mmol} \mathrm{L}^{-1}$ $\left(\mathrm{NH}_{4}\right)_{2} \mathrm{SO}_{4}, 0.02 \%$ Tween $20,5.0 \mathrm{mmol} \mathrm{L} \mathrm{MgCl}_{2}$, $400 \mu \mathrm{mol} \mathrm{L}^{-1} \mathrm{dATP}, 400 \mu \mathrm{mol} \mathrm{L}{ }^{-1} \mathrm{dCTP}, 400 \mu \mathrm{mol} \mathrm{L}-1$ dGTP, $400 \mu \mathrm{mol} \mathrm{L}^{-1} \mathrm{dTTP}, 100 \mathrm{U} \mathrm{mL}^{-1}$ Taq-Purple DNA polymerase, $38 \mathrm{nmol} \mathrm{L}^{-1}$ anti-Taq monoclonal antibody, stabilizers, and additives (Tob-Bio, Prague, Czech Republic)], $7.3 \mu \mathrm{L}$ PCR $\mathrm{H}_{2} \mathrm{O}$ (Top-Bio, Prague, Czech Republic), $2 \mu \mathrm{L}$ template DNA (50 ng $\left.\mu \mathrm{L}^{-1}\right), 0.5$ $\mu \mathrm{L}$ primer $\left(0.1 \mu \mathrm{mol} \mathrm{L} \mathrm{L}^{-1}\right)$, and $0.2 \mu \mathrm{L}$ bovine serum albumin (20 mg mL $\mathrm{mL}^{-1}$ ) (Thermo Fisher Scientific, Waltham, MA, USA). PCR reactions were performed in the T100 Thermal Cycler (Bio-Rad, Irvine, CA, USA), under the following cycling conditions: initial denaturation at $95^{\circ} \mathrm{C}$ for $5 \mathrm{~min}$, followed by 40 cycles of denaturation at $94^{\circ} \mathrm{C}$ for $1 \mathrm{~min}$, annealing at $49-54^{\circ} \mathrm{C}$ for $1 \mathrm{~min}$, and extension at $72^{\circ} \mathrm{C}$ for $2 \mathrm{~min}$, with final extension at $72^{\circ} \mathrm{C}$ for $8 \mathrm{~min}$. The amplified products were electrophoretically separated on $1.5 \%$ agarose gel using the Labnet Enduro Power Station x (Labnet International, NJ, USA). The gels were stained with ethidium bromide (Carl Roth $\mathrm{GmbH}$, Karlsruhe, Germany) and were run at $100 \mathrm{~V}$ for approximately 1.5 hour. The size of the amplified products was estimated using the GeneRuler 100 bp Plus DNA Ladder (Fisher Scientific Lithuania, Vilnius, Lithuania), and the amplified stained products were visualized on a gel with a UV transilluminator. ISSR profiles were scored visually for the presence (1) or absence (0) of bands in the gel; only clear, distinct bands were considered. 
The relative DNA content of 15 regenerants previously subjected to the molecular analysis was measured using flow cytometry. Samples were prepared following a simplified two-step protocol (Dolezel et al., 2007). Approximately $0.5 \mathrm{~cm}^{2}$ in vitro regenerant leaf was chopped simultaneously with an appropriate amount of internal reference standard - in this case, Bellis perennis L., $2 \mathrm{C}=3.38 \mathrm{pg}$ (Schönswetter et al., 2007) -, using a razor blade in $0.5 \mathrm{~mL}$ ice-cold Otto I buffer $\left[0.1 \mathrm{~mol} \mathrm{~L}^{-1}\right.$ citric acid and $0.5 \%(\mathrm{v} / \mathrm{v})$ Tween 20]. The suspension was filtered through a $42-\mu \mathrm{m}$ nylon mesh and incubated for $10 \mathrm{~min}$ at room temperature. A sample was stained with $1.0 \mathrm{~mL}$ Otto II buffer $\left(0.4 \mathrm{~mol} \mathrm{~L}^{-1} \mathrm{Na}_{2} \mathrm{HPO}_{4} \cdot 12 \mathrm{H}_{2} \mathrm{O}\right), 4.0 \mu \mathrm{L} \mathrm{mL}-1$ of the AT-selective fluorescent dye 4',6-diamidino2-phenylindole, and $2.0 \mu \mathrm{L} \mathrm{mL}^{-1}$ 2-mercaptoethanol. After incubation of samples at room temperature for $5 \mathrm{~min}$, the stained nuclei were analyzed with the CyFlow Space cytometer (Sysmex Partec GmbH, Görlitz, Germany) with a UV-diode chip, at a concentration of 3,000 per sample. Histograms were evaluated using the FloMax software, version $2.4 \mathrm{~d}$ (Sysmex Partec GmbH, Görlitz, Germany). DNA ratios were counted by dividing the mean of the G0/G1 peak of the arracacha sample by the mean of the G0/G1 peak of the internal standard.

Karyological analyses were carried out in three control plants. Excised root tips were pre-treated for 3 hours in a saturated para-dichlorobenzene solution and subsequently placed in a fixative solution, consisting of ethanol and acetic acid (3:1) (v/v), where they were kept overnight. The roots were then macerated in a solution of hydrochloric acid with ethanol (1:1) (v/v) for $30 \mathrm{~s}$ and washed in distilled water. The root tip cuttings were squashed in saturated lacto-propionic orcein. The Zeiss $\mathrm{Nu}$ microscope (Carl Zeiss Microscopy GmbH, Jena, Germany) was used to observe the samples.

\section{Results and Discussion}

The callus started to develop from both sectioned parts of the arracacha petiole segments after two weeks of explant cultivation on MS medium supplemented with $0.1 \mathrm{mg} \mathrm{L}^{-1} 2,4-\mathrm{D}$. The frequency of callus initiation from the explants was $88.8 \%$. The callus was of light yellow-green color and of friable texture. It was actively proliferating, grew fast, and, after its initial development within eight weeks, it regularly multiplied every $3-4$ weeks. Within this period, callus FW increased approximately 3-4 fold. After 50 days of cultivation, meristematic centers started to develop on the surface of the callus (Figure 1).

Approximately after three weeks, the callus was transferred to a regeneration medium without plant growth regulators (PGRs), where the regeneration of shoots via organogenesis started to occur. However, two weeks later, regeneration via indirect somatic embryogenesis was also observed, but at lower frequencies (Figure 1). Although, in a previous study on arracacha micropropagation, unipolar shoot structures were developed on the callus induced on a medium with 2,4D (Slíva et al., 2010), this is the first known research in which indirect somatic embryogenesis was observed in arracacha callus culture.

The development of plants via somatic embryogenesis was confirmed by the histological analysis, when embryos at the cotyledonary stage and with closed vascular bundles were identified. After five weeks of morphogenic callus culture on regeneration medium, an average of 12.6 shoots (85.7\%) and 2.1 somatic embryos (14.3\%) were found per $0.5 \mathrm{~g} \mathrm{FW}$ morphogenic callus. Both shoots and somatic embryos regenerated into plants on half-strength MS medium (Figure 1).

These results are similar to those obtained by Stanišić et al. (2015), who found that Iris sibirica L. plants regenerated simultaneously via organogenesis and somatic embryogenesis from a callus previously induced on a medium supplemented with $1.0 \mathrm{mg} \mathrm{L}^{-1}$ 2,4-D. Rocha et al. (2015) attributed the parallel induction of shoot organogenesis and somatic embryogenesis to specific concentrations and types of PGRs, affecting the callus culture. These authors also stressed that the manipulation of in vitro culture conditions might allow these morphogenic pathways to be induced alternatively or simultaneously. This was confirmed by Wang et al. (2008), who studied Pogonatherum paniceum (Lam.) Hack. and found that: low concentrations of 2,4-D led exclusively to indirect shoot organogenesis; relatively high concentrations, to indirect somatic embryogenesis; and intermediate concentrations, ranging from 0.1 to $1.0 \mathrm{mg} \mathrm{L}^{-1} 2,4-\mathrm{D}$, to both types of regeneration from one explant. These findings might indicate that, for arracacha, $0.1 \mathrm{mg}$ 
$\mathrm{L}^{-1}$ 2,4-D represents an intermediate concentration, inducing both types of plant regeneration, whereas increasing or decreasing 2,4-D concentrations might result in strict somatic embryogenesis or shoot organogenesis, respectively. Both regenerative pathways are, however, considered to be complex
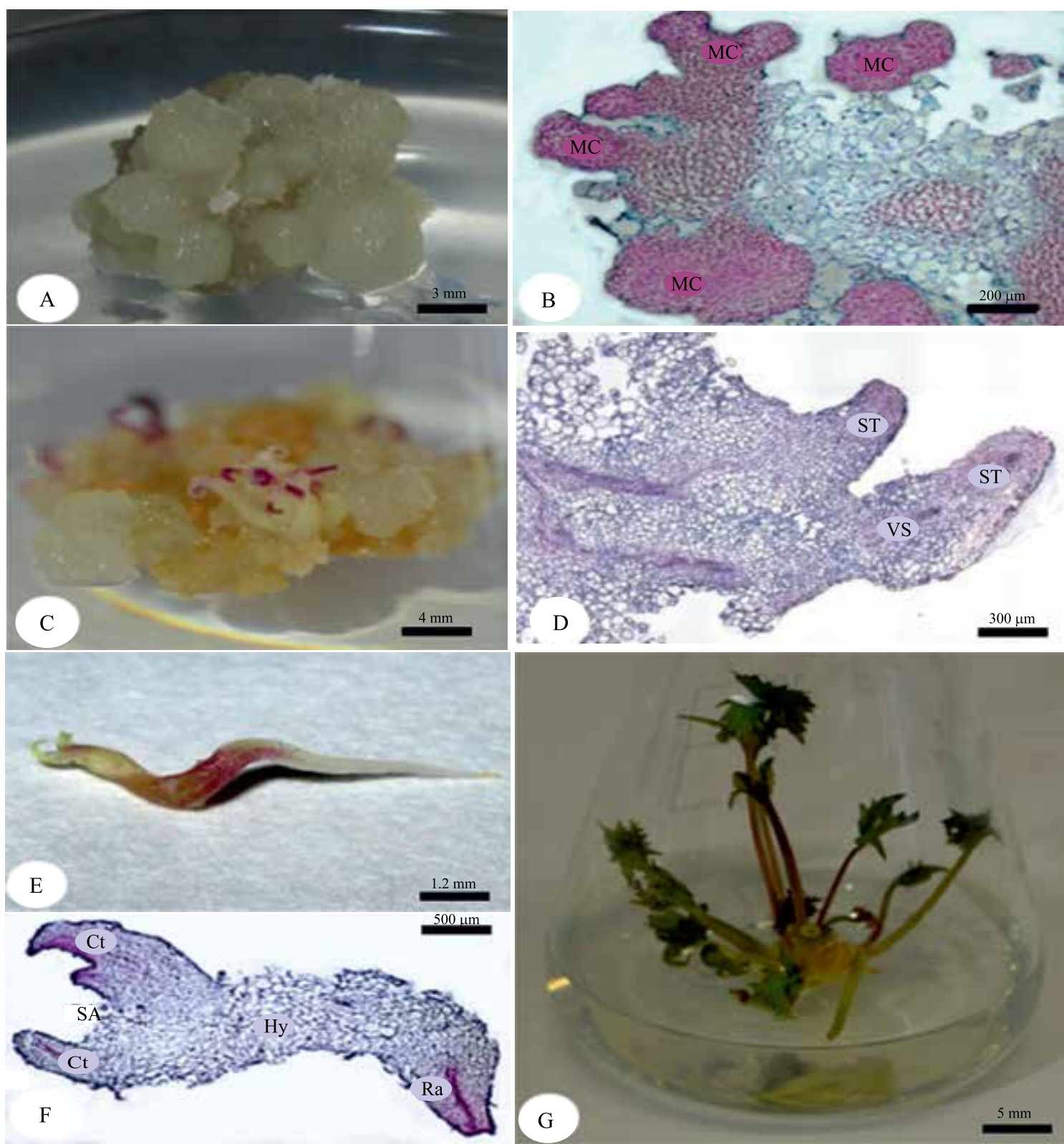

Figure 1. Callus induction and plant regeneration from explants of arracacha (Arracacia xanthorrhiza). A, 50-day-old light yellow-green friable callus with meristematic centers on its surface, cultivated on a medium containing $0.1 \mathrm{mg} \mathrm{L}^{-1}$ 2,4-dichlorophenoxyacetic acid; B, histological analysis of the morphogenic callus with meristematic center (MC); C, shoot regeneration from a callus on a medium without plant growth regulators (PGRs); D, histological analysis of shoot regeneration from a callus cultivated on a medium without PGRs, where ST is the shoot tip and VS is the vascular system; E, matured somatic embryo obtained from regeneration MS medium without PGRs; F, histological analysis of early cotyledonary somatic embryo, where $\mathrm{Ct}$ is the cotyledon, Hy is the hypocotyl, Ra is the radicle, and SA is the shoot apex; and G, plant recovered from a callus on half-strength MS medium. 
developmental processes that are supposed to involve not only different hormonal requirements, but also a series of biochemical and morphological changes (Yang \& Zhang, 2010; Rocha, 2015).

In the present study, the ISSR analysis was used to reveal potential somaclonal variation among in vitro regenerated arracacha plants. Out of the 20 ISSR primers tested, 18 produced clear and reproducible bands, and each of these primers provided at least three bands per sample (Table 1). A total of 1,584 fragments were generated from all tested regenerants and a control plant. The number of scored fragments per primer ranged from 3 to 10 , and the average number of bands per primer was 5.5. From the total number of bands, $4.04 \%$ were polymorphic and they were generated by two primers, namely UBC 807 and UBC836. Each of these primers produced two polymorphic bands, respectively: 500 and $600 \mathrm{bp}$, both extra bands; and 1,300 and $350 \mathrm{bp}$, absent and extra bands (Figure 2). Genetic variability was revealed in 4 out of 15 regenerants - i.e., R8, R13, R14, and R15 -, representing $26.7 \%$ of all tested samples. The results obtained from the ISSR analysis in arracacha showed that plant regeneration from a callus is responsible for somaclonal variation arising from point mutations.

These results are in alignment with those of other studies, where somaclonal variation in plantlets regenerated from undifferentiated tissue was also detected using the ISSR analysis. The following mean polymorphisms, for example, were found: $41.39 \%$ for Jatropha curcas L. after plant regeneration via indirect organogenesis and within successive subcultures (Soares et al., 2016); 12.2\% for Amorphophallus rivieri Durieu, in plants regenerated through indirect organogenesis (Hu et al., 2011); and $7.19 \%$ for Smallanthus sonchifolius (Poepp. and Endl.) H. Robinson, in somatic embryo-derived plants (Viehmannova et al., 2014). ISSR has also been reported to be a powerful technique to detect genetic fidelity among in vitro regenerated plants from nodal cultures

Table 1. Details on the inter-simple sequence repeat (ISSR) analysis of 15 in vitro regenerants and a control plant of arracacha (Arracacia xanthorrhiza).

\begin{tabular}{|c|c|c|c|c|c|c|c|c|c|}
\hline $\begin{array}{l}\text { Primer } \\
\text { code }^{(1)}\end{array}$ & $\begin{array}{l}\text { Sequence } \\
5^{\prime}-3^{\prime(2)}\end{array}$ & $\begin{array}{l}\mathrm{T}_{\mathrm{an}}{ }^{(3)} \\
\left({ }^{\circ} \mathrm{C}\right)\end{array}$ & $\begin{array}{l}\text { No. of bands } \\
\text { per primer }\end{array}$ & $\begin{array}{l}\text { Total no. } \\
\text { of bands }\end{array}$ & $\begin{array}{l}\text { No. of polymorphic } \\
\text { bands per primer }\end{array}$ & $\begin{array}{c}\mathrm{PPB}^{(4)} \\
(\%)\end{array}$ & $\begin{array}{l}\text { No. of polmor- } \\
\text { phic regenerants }\end{array}$ & $\begin{array}{l}\text { Polymorphic } \\
\text { regenerants }\end{array}$ & $\begin{array}{c}\text { Range of } \\
\text { amplification (bp) }\end{array}$ \\
\hline UBC 807 & $(\mathrm{AG})_{8} \mathrm{~T}$ & 48 & 4 & 64 & 2 & 50 & 2 & R14, R15 & $250-650$ \\
\hline UBC809 & $(\mathrm{AG})_{8} \mathrm{G}$ & 50 & 4 & 64 & - & 0 & 0 & - & $290-700$ \\
\hline UBC 810 & $(\mathrm{GA})_{8} \mathrm{~T}$ & 49 & 5 & 80 & - & 0 & 0 & - & $600-1,300$ \\
\hline UBC 812 & $(\mathrm{GA})_{8} \mathrm{~A}$ & 50 & 5 & 80 & - & 0 & 0 & - & $380-1,000$ \\
\hline UBC823 & $(\mathrm{TC})_{8} \mathrm{C}$ & 54 & 3 & 48 & - & 0 & 0 & - & $600-1,700$ \\
\hline UBC824 & $(\mathrm{AG})_{8} \mathrm{YT}$ & 55 & 10 & 160 & - & 0 & 0 & - & $200-1,900$ \\
\hline UBC 828 & $(\mathrm{TG})_{8} \mathrm{~A}$ & 48 & 5 & 80 & - & 0 & 0 & - & $600-1,300$ \\
\hline UBC829 & $(\mathrm{TG})_{8} \mathrm{C}$ & 50 & 4 & 64 & - & 0 & 0 & - & $520-1,900$ \\
\hline UBC834 & $(\mathrm{AG})_{8} \mathrm{YT}$ & 50 & 5 & 80 & - & 0 & 0 & - & $210-1,900$ \\
\hline UBC835 & $(\mathrm{AG})_{8} \mathrm{YC}$ & 51 & 5 & 80 & - & 0 & 0 & - & $450-1,200$ \\
\hline UBC836 & $(\mathrm{AG})_{8} \mathrm{YA}$ & 48 & 9 & 144 & 2 & 22 & 2 & $\mathrm{R} 8, \mathrm{R} 13$ & $200-1,300$ \\
\hline UBC 840 & $(\mathrm{GA})_{8} \mathrm{YT}$ & 52 & 6 & 96 & - & 0 & 0 & - & $400-1,000$ \\
\hline UBC841 & $(\mathrm{GA})_{8} \mathrm{YC}$ & 48 & 6 & 96 & - & 0 & 0 & - & $200-700$ \\
\hline UBC 844 & $(\mathrm{CT})_{8} \mathrm{RC}$ & 52 & 8 & 128 & - & 0 & 0 & - & $480-1,300$ \\
\hline UBC847 & $(\mathrm{CA})_{8} \mathrm{RC}$ & 54 & 3 & 48 & - & 0 & 0 & - & $590-1,400$ \\
\hline UBC 851 & $(\mathrm{GT})_{8} \mathrm{G}$ & 52 & 7 & 112 & - & 0 & 0 & - & $700-1,700$ \\
\hline UBC 855 & $(\mathrm{AC})_{8} \mathrm{YT}$ & 54 & 7 & 112 & - & 0 & 0 & - & $450-1,800$ \\
\hline UBC856 & $(\mathrm{AC})_{8} \mathrm{YA}$ & 49 & 3 & 48 & - & 0 & 0 & - & $800-1,600$ \\
\hline Total & & & 99 & 1584 & 4 & 4.04 & 4 & & \\
\hline
\end{tabular}


or adventitious shoots in many plant species, such as Sphagneticola calendulacea (L.) Pruski (Kundu et al., 2017), Puya berteroniana Mez (Viehmannova et al., 2016), Cornus alba L. (Ilczuk \& Jacygrad, 2016), and Phyllanthus fraternus Webster (Upadhyay et al., 2015), showing the suitability of this method for a rapid and reliable genetic screening of in vitro regenerants.

In contrast to the ISSR analysis, flow cytometry did not reveal any variation among callus-derived arracacha plants in terms of ploidy level. The DNA ratios in all samples ranged between 1.680 and 1.710, showing no differences in the relative DNA content among samples. The chromosome number in the somatic cells of the control plant material was $2 n=44$, which corresponds to the tetraploid chromosomal level (4x) (Figure 2). These results indicate that, despite the general presumption that plant material grown in tissue culture shows especially unstable DNA content (Sliwinska, 2018), arracacha plants proved to be stable and not susceptible to ploidy level changes during in vitro cultivation. These results are similar to those of Viehmannova et al. (2014), who studied another Andean root crop, S. sonchifolius, and detected somaclonal variation at the point mutation level in

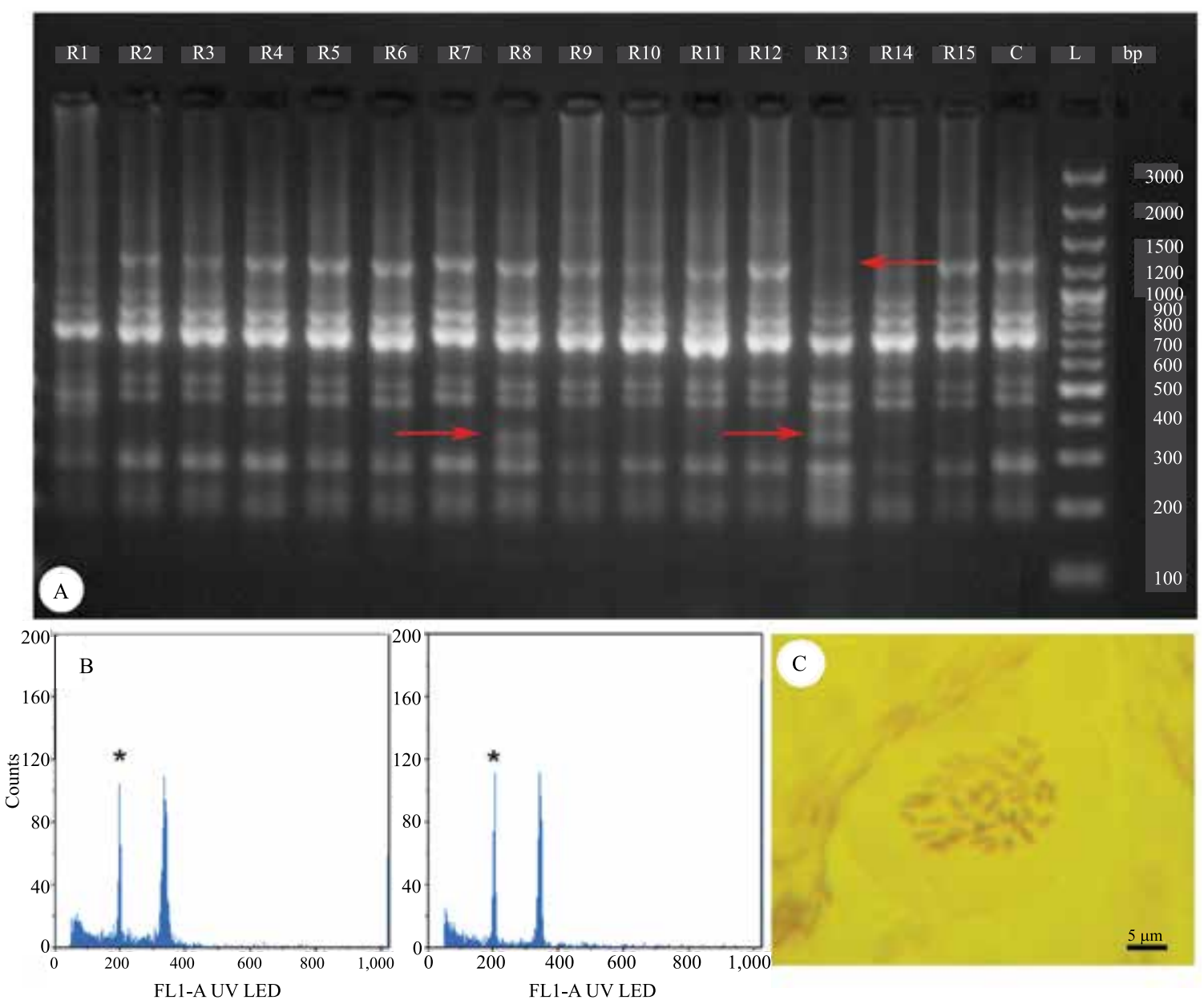

Figure 2. Molecular, flow cytometry, and karyological analyses of in vitro regenerants of arracacha (Arracacia xanthorrhiza). A, inter-simple sequence repeat profile of in vitro regenerants and a control plant using the UBC836 primer, where R1-R15 are 15 randomly chosen regenerants, $\mathrm{C}$ is the control plant, $\mathrm{L}$ is the ladder, and arrows indicate the position of the polymorphic bands; B, representative histograms showing relative fluorescence intensity of the control plant (on the left) and of a randomly chosen in vitro regenerant (on the right), with the peak of the internal standard, Bellis perennis, indicated with an asterisk; and C, chromosome counts in root tips of arracacha $(2 n=4 x=44)$. 
somatic embryo-derived plants using ISSR markers; however, no genomic changes were proven by flow cytometry.

The present study shows the first findings on the induction and detection of somaclonal variation in arracacha as a possible source for plant genetic improvement (Cao et al., 2016), especially when other breeding methods are limited. Since the genetically variable somaclones in many crops positively changed agronomic traits (Bairu et al., 2011), this breeding method could generate new arracacha genotypes, with, for example, improved disease tolerance, higher root yields, or higher starch content. However, within a somaclonal breeding program, the limitations of this method should also be taken into account, i.e., that it is not possible to predict the outcomes of the somaclonal variation process or that some variations could have negative traits (Krishna et al., 2016). Therefore, a thorough evaluation of newly developed genotypes is of high priority.

\section{Conclusions}

1. Indirect morphogenesis in arracacha (Arracacia xanthorrhiza) can be achieved using 2,4-dichlorophenoxyacetic acid by both regeneration pathways, shoot organogenesis and somatic embryogenesis.

2. Arracacha plant regeneration via indirect morphogenesis is responsible for the induction of somaclonal variation.

3. The inter-simple sequence repeat analysis is a valuable tool to reveal genetic variation among in vitro regenerants of arracacha.

4. The induction of somaclonal variation can be used in arracacha improvement to widen the species genetic variability.

\section{Acknowledgments}

To Internal Grant Agency of Faculty of Tropical AgriSciences of Czech University of Life Sciences Prague (project number 20185015) and to the Ministry of Agriculture of the Czech Republic (project number RO0418), for financial support; and to Vlasta Jarolimova from Institute of Botany of the Czech Academy of Sciences, for assistance with chromosome counting.

\section{References}

BAIRU, M.W.; AREMU, A.O.; VAN STADEN, J. Somaclonal variation in plants: causes and detection methods. Plant Growth Regulation, v.63, p.147-173, 2011. DOI: https://doi.org/10.1007/ s10725-010-9554-x.

CAO, Z.; SUI, S.; CAI, X.; YANG, Q.; DENG, Z. Somaclonal variation in 'Red Flash' caladium: morphological, cytological and molecular characterization. Plant Cell, Tissue and Organ Culture, v.126, p.269-279, 2016. DOI: https://doi.org/10.1007/ s11240-016-0996-3.

CARVALHO, A.D.F.; MADEIRA, N.R.; SILVA, G.O. Adaptability and stability of commercial yield of arracacha in southern region of Minas Gerais State. Horticultura Brasileira, v.36, p.100-105, 2018. DOI: https://doi.org/10.1590/s0102-053620180117.

DOLEZEL, J.; GREILHUBER, J.; SUDA, J. Estimation of nuclear DNA content in plants using flow cytometry. Nature Protocols, v.2, p.2233-2244, 2007. DOI: https://doi.org/10.1038/ nprot.2007.310.

HERMANN, M. Arracacha. Arracacia xanthorrhiza Bancroft. In: HERMANN, M.; HELLER, J. (Ed.). Andean roots and tubers: Ahipa, arracacha, maca and yacon. Rome: IPGRI, 1997. (Promoting the conservation and use of underutilized and neglected crops, 21).

HU, J.-B.; LI, Q.; LI, J. ISSR analysis of somaclonal variation in callus-derived plants of Amorphophallus rivieri Durieu. Acta Biologica Cracoviensia. Series Botanica, v.53, p.120-124, 2011. DOI: https://doi.org/10.2478/v10182-011-0017-0.

ILCZUK, A.; JACYGRAD, E. In vitro propagation and assessment of genetic stability of acclimated plantlets of Cornus alba L. using RAPD and ISSR markers. In Vitro Cellular \& Developmental Biology - Plant, v.52, p.379-390, 2016. DOI: https://doi.org/10.1007/s11627-016-9781-6.

KRISHNA， H.; ALIZADEH， M.; SINGH， D.; SINGH, U.; CHAUHAN, N.; EFTEKHARI, M.; SADH, R.K. Somaclonal variations and their applications in horticultural crops improvement. 3 Biotech, v.6, art.54, 2016. DOI: https://doi.org/10.1007/s13205-016-0389-7.

KUNDU, S.; SALMA, U.; ALI, M.N.; MANDAL, N. Factors influencing large-scale micropropagation of Sphagneticola calendulacea (L.) Pruski and clonality assessment using RAPD and ISSR markers. In Vitro Cellular \& Developmental Biology - Plant, v.53, p.167-177, 2017. DOI: https://doi.org/10.1007/s11627017-9824-7.

LAKSHMANAN, V.; VENKATARAMAREDDY, S.R.; NEELEARNE, B. Molecular analysis of genetic stability in longterm micropropagated shoots of banana using RAPD and ISSR markers. Electronic Journal of Biotechnology, v.10, p.106-113, 2007. DOI: https://doi.org/10.2225/vol10-issuel-fulltext-12.

MURASHIGE, T.; SKOOG, F. A revised medium for rapid growth and bio assays with tobacco tissue cultures. Physiologia Plantarum, v.15, p.473-497, 1962. DOI: https://doi.org/10.1111/j.1399-3054.1962.tb08052.x. 
NATIONAL RESEARCH COUNCIL. Lost crops of the Incas: little-known plants of the Andes with promise for worldwide cultivation. Washington: National Academy Press, 1989. DOI: https://doi.org/10.17226/1398.

ORÍLIO, A.F.; LUCINDA, N.; DUSI, A.N.; NAGATA, T.; INOUE-NAGATA, A.K. Complete genome sequence of arracacha mottle virus. Archives of Virology, v.158, p.291-295, 2013. DOI: https://oi.org/10.1007/s00705-012-1473-X.

REDDY, M.P.; SARLA, N.; SIDDIQ, E.A. Inter simple sequence repeat (ISSR) polymorphism and its application in plant breeding. Euphytica, v.128, p.9-17, 2002. DOI: https://doi.org/10.1023/A:1020691618797.

ROCHA, D.I.; MONTE-BELlO, C.C.; DORNELAS, M.C. Alternative induction of de novo shoot organogenesis or somatic embryogenesis from in vitro cultures of mature zygotic embryos of passion fruit (Passiflora edulis Sims) is modulated by the ratio between auxin and cytokinin in the medium. Plant Cell, Tissue and Organ Culture, v.120, p.1087-1098, 2015. DOI: https://doi.org/10.1007/s11240-014-0663-5.

SATO, M.; HOSOKAWA, M.; DOI, M. Somaclonal variation is induced de novo via the tissue culture process: a study quantifying mutated cells in Saintpaulia. PLoS ONE, v.6, e23541, 2011. DOI: https://doi.org/10.1371/journal.pone.0023541.

SCHÖNSWETTER, P.; SUDA, J.; POPP, M.; WEISSSCHNEEWEISS, H.; BROCHMANN, C. Circumpolar phylogeography of Juncus biglumis (Juncaceae) inferred from AFLP fingerprints, cpDNA sequences, nuclear DNA content and chromosome numbers. Molecular Phylogenetics and Evolution, v.42, p.92-103, 2007. DOI: https://doi.org/10.1016/j. ympev.2006.06.016.

SLÍVA, Š.; VIEHMANNOVÁ, I.; VÍTÁMVÁS, J. Micropropagation and morphogenesis of arracacha (Arracacia xanthorrhiza Bancroft). Agricultura Tropica et Subtropica, v.43, p.206-211, 2010.

SLIWINSKA, E. Flow cytometry - a modern method for exploring genome size and nuclear DNA synthesis in horticultural and medicinal plant species. Folia Horticulturae, v.30, p.103128, 2018. DOI: https://doi.org/10.2478/fhort-2018-0011.

SOARES, D.M.M.; SATTLER, M.C.; FERREIRA, M.F. da S.; PRAÇA-FONTES, M.M. Assessment of genetic stability in three generations of in vitro propagated Jatropha curcas L. plantlets using ISSR markers. Tropical Plant Biology, v.9, p.229-238, 2016. DOI: https://doi.org/10.1007/s12042-016-9171-6.
STANIŠIĆ, M.; RASPOR, M.; NINKOVIĆ, S.; MILOŠEVIĆ, S.; ĆALIĆ, D.; BOHANEC, B.; TRIFUNOVIĆ, M.; PETRIĆ, M.; SUBOTIĆ, A.; JEVREMOVIĆ, S. Clonal fidelity of Iris sibirica plants regenerated by somatic embryogenesis and organogenesis in leaf-base culture - RAPD and flow cytometer analyses. South African Journal of Botany, v.96, p.42-52, 2015. DOI: https://doi.org/10.1016/j.sajb.2014.10.014.

UPADHYAY, R.; KASHYAP, S.P.; TIWARI, K.N., SINGH, K.; SINGH, M. Micropropagation of Phyllanthus fraternus Webster (Euphorbiaceae) from field-derived shoot tip explant and assessment of its genetic fidelity. Brazilian Journal of Botany, v.38, p.517525, 2015. DOI: https://doi.org/10.1007/s40415-015-0171-9.

VIEHMANNOVA, I.; BORTLOVA, Z; VITAMVAS, J; CEPKOVA, P.H.; ELIASOVA, K.; SVOBODOVA, E.; TRAVNICKOVA, M. Assessment of somaclonal variation in somatic embryo-derived plants of yacon [Smallanthus sonchifolius (Poepp. and Endl.) H. Robinson] using inter simple sequence repeat analysis and flow cytometry. Electronic Journal of Biotechnology, v.17, p.102-106, 2014. DOI: https://doi.org/10.1016/j.ejbt.2013.12.011.

VIEHMANNOVA, I.; CEPKOVA, P.H.; VITAMVAS, J.; STREBLOVA, P.; KISILOVA, J. Micropropagation of a giant ornamental bromeliad Puya berteroniana through adventitious shoots and assessment of their genetic stability through ISSR primers and flow cytometry. Plant Cell, Tissue and Organ Culture, v.125, p.293-302, 2016. DOI: https://doi.org/10.1007/ s11240-016-0949-x.

VONDRÁKOVÁ, Z.; ELIÁŠOVÁ, K.; VÁGNER, M., MARTINCOVÁ, O.; CVIKROVÁ, M. Exogenous putrescine affects endogenous polyamine levels and the development of Picea abies somatic embryos. Plant Growth Regulation, v.75, p.405-414, 2015. DOI: https://doi.org/10.1007/s10725-014-0001-2.

WANG, W.; ZHAO, X.; ZHUANG, G.; WANG, S.; CHEN, F. Simple hormonal regulation of somatic embryogenesis and/or shoot organogenesis in caryopsis cultures of Pogonatherum paniceum (Poaceae). Plant Cell, Tissue and Organ Culture, v.95, p.57-67, 2008. DOI: https://doi.org/10.1007/s11240-008-9414-9.

YANG, X.; ZHANG, X. Regulation of somatic embryogenesis in higher plants. Critical Reviews in Plant Sciences, v.29, p.36-57, 2010. DOI: https://doi.org/10.1080/07352680903436291.

ZIETKIEWICZ, E.; RAFALSKI, A.; LABUDA, D. Genome fingerprinting by simple sequence repeat (SSR)-anchored polymerase chain reaction amplification. Genomics, v.20, p.176183, 1994. DOI: https://doi.org/10.1006/geno.1994.1151.

\section{ERRATA: Assessment of somaclonal variation in indirect morphogenesis-derived plants of Arracacia xanthorrhiza}

In the paper "Assessment of somaclonal variation in indirect morphogenesis-derived plants of Arracacia xanthorrhiza", DOI: 10.1590/S1678-3921.pab2019.v54.00301, published in Pesquisa Agropecuária Brasileira, v.54, e00301, 2019, on page 2, left column, second paragraph, line 6, where it reads:

"Slerotinia sclerotiorum", it should read: "Sclerotinia sclerotiorum". 